\title{
Black Stink Bug Proxys punctulatus (Palisot) (Insecta: Hemiptera: Pentatomidae) 1
}

Celina Gomez and Russell F. Mizell III

\section{Introduction}

The biology of the black stink bug, Proxys punctulatus (Palisot), is not well known. It has a broad geographical range in the Americas but does not appear to damage agricultural crops as do other more important pentatomids. Black stink bugs appear to be facultative feeders on plants and other insects.

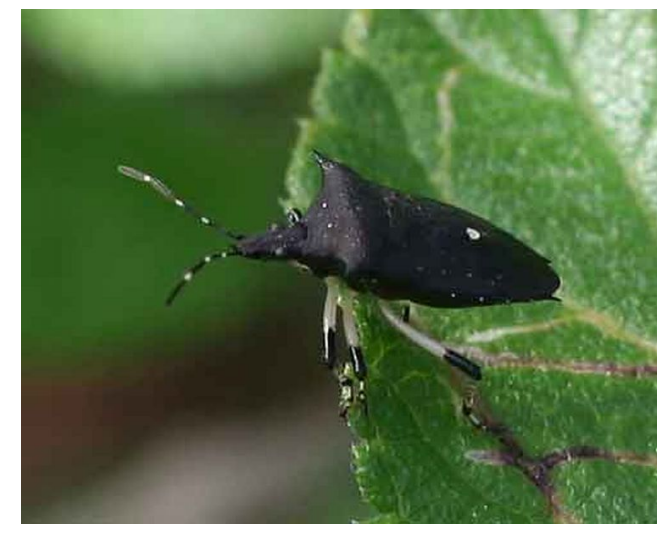

Figure 1. Adult black stink bug, Proxys punctulatus (Palisot), on lantana. Credits: Bill Brower, BugGuide.net

\section{Distribution}

The range of $P$. punctulatus extends through Central America ( Honduras, Mexico, Costa Rica, El Salvador, Nicaragua), South America (Brazil), and the Caribbean islands of Puerto Rico, Santo Domingo and Cuba. In the U.S., it is found from North Carolina to Southern Florida and west through southern Indiana and southern Illinois to Oklahoma and Texas.

\section{Description}

Adults: The adults are usually colored black with black and cream legs. The head and humeral angles of the pronotum are pointed. They can be distinguished from other pentatomids by the laterally directed humeral spines, acute and reflexed tylus (distal part of the clypeus) which strongly surpasses the juga (mandibular plate in Hemiptera), and black ground color with a yellow spot at the apex of the scutellum. Their length is approximately of 11 to $13 \mathrm{~mm}$.

1. This document is EENY-432, one of a series of Featured Creatures from the Entomology and Nematology Department, Florida Cooperative Extension Service, Institute of Food and Agricultural Sciences, University of Florida. Published: February 2009. This document is also available on Featured Creatures website at http://entomology.ifas.ufl.edu/creatures. Please visit the EDIS website at http://edis.ifas.ufl.edu. Additional information on these organisms, including many color photographs, is available at the Entomology and Nematology Department website at http://entnemdept.ifas.ufl.edu/.

2. Celina Gomez, undergraduate intern, North Florida Research and Education Center (REC)-Quincy FL; Russell F. Mizell III, assistant program director and professor, North Florida REC-Quincy FL; Florida Cooperative Extension Service, Institute of Food and Agricultural Sciences, University of Florida, Gainesville FL 32611.

The Institute of Food and Agricultural Sciences (IFAS) is an Equal Opportunity Institution authorized to provide research, educational information and other services only to individuals and institutions that function with non-discrimination with respect to race, creed, color, religion, age, disability, sex, sexual orientation, marital status, national origin, political opinions or affiliations. U.S. Department of Agriculture, Cooperative Extension Service, University of Florida, IFAS, Florida A. \& M. University Cooperative Extension Program, and Boards of County Commissioners Cooperating. Millie Ferrer-Chancy, Interim Dean 


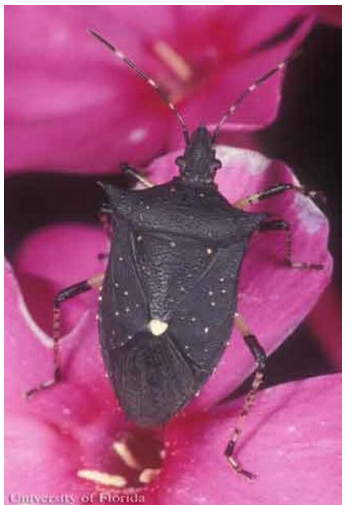

Figure 2. Dorsal view of an adult black stink bug, Proxys punctulatus (Palisot), on phlox. Credits: Lyle J. Buss, University of Florida

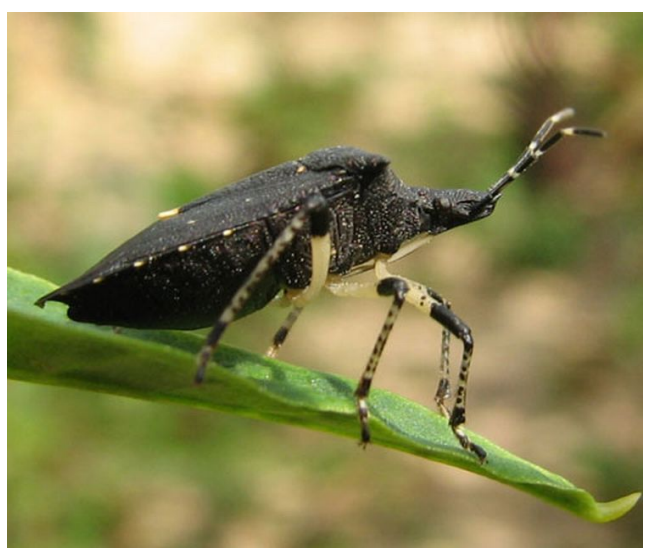

Figure 3. Lateral view of an adult black stink bug, Proxys punctulatus (Palisot). Credits: Edward Trammel, BugGuide.net

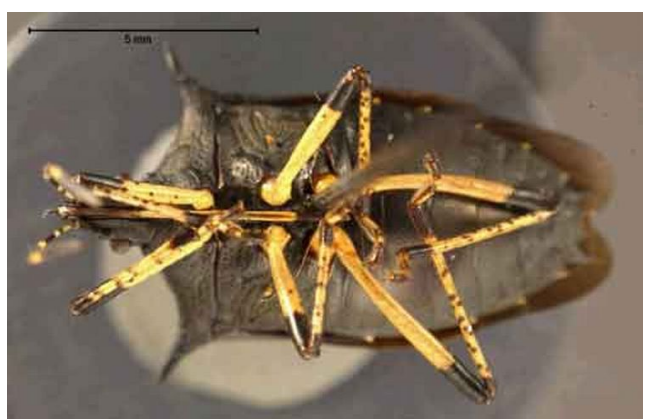

Figure 4. Ventral view of an adult black stink bug, Proxys punctulatus (Palisot). Credits: Harvard University

Eggs: The eggs are usually laid singly and sometimes in pairs, which is a species characteristic. All other North American pentatomids lay their eggs in clusters. The length of the eggs is $1.05 \mathrm{~mm}$ and their width $\sim 0.96 \mathrm{~mm}$. They are white and slightly ovoid.

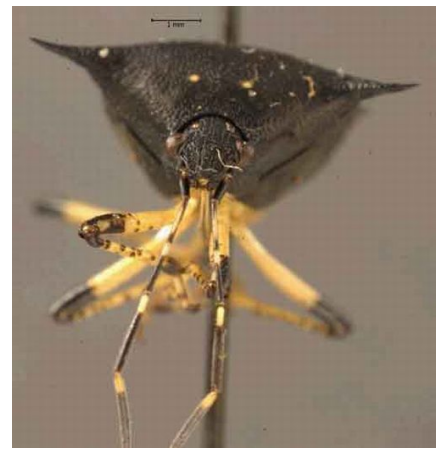

Figure 5. Frontal view of an adult black stink bug, Proxys punctulatus (Palisot). Credits: Harvard University

Nymphs: The nymphs go through five instars to complete development, which are distinguishable by differences in size, punctuation, antennal segment lengths and the shape of the meso and metatona. All of these differences become obvious as the insect matures. They also change in color from a light translucent brown to a dark black that characterizes them as they mature.

\section{Life Cycle and Biology}

Proxys punctulatus overwinter as adults and have been found in forest leaf litter around and beneath logs. The adults emerge during June and oviposition occurs one to two weeks afterwards. Their complete life cycle has been estimated to last 54 days.

Black stink bugs usually feed and copulate on inflorescences and leaves of plants growing along margins of lowlands woods. One experiment showed that pairs remained in copulation for an estimated 1.5 to 4 hours. It is not clear whether this species is uni-or bivoltine (one or two generation) because of inconclusive data.

Their unusual coloration stands out, perhaps signaling that they are distasteful for predators like birds. Some predatory stink bugs are also black, and are capable of stabbing with a strong proboscis, so perhaps the dark color also relates to stabbing behavior as a deterrent.

\section{Hosts}

Black stink bugs have been collected in cotton, soybean and citrus. They feed on plant juices, with some documented association with Commelina (dayflowers) species. Although the black stink bug is 
a phytophagous species, it can also be predaceous, and has been found attacking insect larvae in cotton.

\section{Damage}

Black stink bugs feed by sucking out plant juices, producing disfigured leaves and discolored areas on plant stems. Because the bugs never reach high populations, their damage to plants is usually insignificant.

\section{Selected References}

Duffie et al. Susceptibility of Cotton to the Black Stink Bug, Proxys punctulatus. Georgia Cotton Research and Extension Report 2001. 261-262.

Green JK, Bundy CS, Robertson PM, Leon BR. 2006. Identification and monitoring of common boll-feeding bugs in cotton. Cotton Incorporated. pp 12.

Mizell RF. (2008). Monitoring stink bugs with the Florida stink bug trap. Insect Traps and Sampling. http://ufinsect.ifas.ufl.edu/stink_bugs/stink_bugs.htm (3 April 2008).

Mizell RF. (2005). Stink bugs and leaffooted bugs are important fruit, nut, seed and vegetable pests. EDIS. UF/IFAS. ENY-718. http://edis.ifas.ufl.edu/IN534 (3 April 2008)

Vangeison KW, McPherson JE. 1975. History and laboratory rearing of Proxys punctulatus (Hemiptera: Pentatomidae) with descriptions of immature stages. Annals of the Entomological Society of America. 68: 25-30. 